\title{
CAÍN (GÉNESIS 4,1-16): SU PRESENCIA EN LA LITERATURA
}

\section{Resumen}

Uno de los recientes avances en las ciencias bíblicas consiste en el estudio del impacto de la Biblia en la historia de la cultura y en la literatura en particular. En el presente artículo se analizan las razones detrás del marcado interés por la figura de Caín en el siglo XIX y su relación con temas fundamentales de la Ilustración y el romanticismo. Con el triunfo de la Revolución francesa emerge un sentido de rebelión social que reivindica la figura de Caín. Este no será ya la encarnación del pecador, sino, por el contrario, la figura del héroe que se rebela contra una tiranía injusta. Se estudia este giro en la comprensión del personaje y la forma en que la realidad social influye en la conformación de las ideas religiosas.

Palabras clave: Biblia y cultura. Génesis. Caín. Hermenéutica.

\section{Biblia y literatura}

Importantes estudios históricos del siglo xx muestran que la recepción de la Biblia ha encontrado una importante resonancia en el arte, y de modo particular en la literatura. La literatura ha mostrado ser capaz de hablar de la Biblia de otro modo, con un lenguaje más cercano a la experiencia humana. La correlación entre literatura y Biblia se muestra prometedora. La intertextualidad se plantea hoy como una tarea insoslayable en los estudios bíblicos. Numerosas publicaciones especializadas han visto la luz en las últimas décadas en el campo de literatura y Biblia.

En primer lugar podemos mencionar los estudios dedicados a literaturas específicas, como los dos volúmenes editados en 1999 por Heinrich 
Schmidinger dedicados a La Biblia en la literatura alemana del siglo $\mathrm{XX}^{1}$; los tres volúmenes editados por Pietro Gibellini sobre La Biblia en la literatura italiana ${ }^{2}$; el Diccionario de la Biblia en la literatura francesa, editado en 2003 por Claudia Jullien ${ }^{3}$; el importante Diccionario de tradiciones bíblicas en la literatura inglesa, editado en 1992 por David L. Jeffrey ${ }^{4}$; la obra en tres volúmenes dedicada a La Biblia en la literatura española, editada por Gregorio del Olmo Lete ${ }^{5}$, la reciente obra La Biblia en la literatura hispanoamericana ${ }^{6}$.

En segundo lugar, pueden mencionarse obras de carácter más general, como la valiosa guía temática y bibliográfica de Gregorio del Olmo Lete La Biblia hebrea en la literatura ${ }^{7}$; la obra clásica de Liptzin Temas bíblicos en la literatura universal ${ }^{8}$; La Biblia en literatura, editada en 1997 por Pierre-Marie Beaude ${ }^{9}$, o la reciente obra de Karin Schöpflin La Biblia en la literatura universal ${ }^{10}$.

En tercer lugar tenemos obras consagradas a temas específicos, como el Léxico de personajes bíblicos: su presencia en el judaísmo, el islam, la poesía, la música y el arte, editado en 2004 por Martin Bocian ${ }^{11}$; el Diccionario bíblico cultural y literario de C. Labre ${ }^{12}$; el Diccionario de la Biblia y la cultura occidental ${ }^{13}$ o el Diccionario cultural de la Biblia ${ }^{14}$. Cabe

1 H. Schmidinger (ed.), Die Bibel in der deutschsprachigen Literatur des 20. Jahrhunderts, Mainz 1999, Band 1: Formen und Motive; Band 2: Personen und Figuren.

2 P. GiBellinı (ed.), La Bibbia nella letteratura italiana, Brescia, 2009-2011. Vol. I: Dall'Illuminismo al Decadentismo. Vol. II: L'età contemporánea. Vol. III: Antico Testamento.

${ }^{3}$ C. Jullien, Dictionnaire de la Bible dans la littérature française, figures, thèmes, symboles, auteurs, Paris 2003.

4 D. L. JefFrey, A Dictionary of Biblical Tradition in English Literature, Grand Rapids 1992.

${ }^{5}$ G. Del Olmo Lete, La Biblia en la literatura española, vols. I-III, Madrid 2008-2010. Vol. I: La Edad Media. Vol. II: El Siglo de Oro. Vol. III: Edad Moderna.

6 D. Attala - G, FABry, La Biblia en la literatura hispanoamericana, Madrid 2016.

7 G. Del Olmo Lete, La Biblia hebrea en la literatura, Barcelona 2010.

8 S. LIPTZIN, Biblical Themes in World Literature, Hoboken (NJ) 1985.

9 P.-M. Beaude, La Bible en littérature, Paris 1997.

10 K. Schöpflin, Die Bibel in der Weltliteratur, Tübingen 2011.

11 M. BocIan, Lexikon der biblischen Personen: Mit ihrem Fortleben in Judentum, Christentum, Islam, Dichtung, Musik und Kunst, Stuttgart 2004.

12 C. LABRE, Dictionnaire biblique culturel et littéraire, Paris 2002.

${ }_{13}$ M. A. Beavis - M. J. Gilmour (eds.), Dictionary of the Bible and Western Culture, Sheffield 2012.

14 D. FoulLlot et al., Dictionnaire culturel de la Bible, Paris 2005. 
mencionar finalmente la aparición en diccionarios bíblicos y teológicos contemporáneos de la entrada "Literatura", como el artículo "Biblia y literatura española", de Luis Vázquez ${ }^{15}$, "Biblia y literatura (italiana)", de Umberto Colombo $^{16}$, el de "Literatura y religión", de P. Gerlitz y otros ${ }^{17}$, el artículo sobre "Literatura y teología", de G. Langenhorst ${ }^{18}$, o los números especiales dedicados por la revista francesa Philosophie al Antiguo Testamento releído por Kant, Eco, Maquiavelo, Lévinas, Freud. Kierkegaard, Nietzsche y Hegel, entre otros ${ }^{19}$; al Nuevo Testamento releído por Arendt, Kant, Nietzsche, Engels, Lacan, Sartre y Leibniz, entre otros ${ }^{20}$, así como el número de Le Magazine Littéraire titulado "La Bible, le Livre des écrivains" 21. Los estudios dedicados a motivos y personajes bíblicos en autores particulares son tan numerosos que es imposible citar siquiera los más importantes. Guías bibliográficas enteras han sido escritas únicamente para este fin.

El artista en general y el literato en particular tienen una forma particular de captar lo esencial de su circunstancia y de expresarlo de tal modo que el contacto con su obra amplía y enriquece nuestro horizonte de comprensión. Baste esta referencia general a algunas obras de las últimas décadas sobre este tema para mostrar que el asunto de motivos y personajes bíblicos en la literatura es una vasta e importante área de estudio. Nuestro artículo pretende estudiar una dimensión del motivo literario de Caín en la literatura moderna y contemporánea, citando algunas de las obras más relevantes para este tema.

15 L. Vázquez, “Biblia y literatura española”, en P. Rossano - G. RaVASI - A. GIRLANDA (eds.), Nuevo diccionario de teología bíblica, Madrid 1990, 214-234.

16 U. Colombo, “Bibbia e letteratura”, en P. Rossano - G. Ravasi - A. GIRLANDa, Nuovo dizionario di teologia biblica, Milano 1988, 192-209.

17 P. Gerlitz et al., “Literatur und Religion”, en G. MülLer (ed.), Theologische Realenzyklopädie, Berlin 2000, Band 18: 233-306, extenso artículo colectivo (73 páginas).

18 G. Langenhorst, "Literatur und Theologie“, en P. Eicher (ed.), Neues Handbuch Theologischer Grundbegriffe, München 2005, Band 2: 506-523.

19 Philosophie Magazine. Hors-Série. La Bible des Philosophes. L'Ancient Testament relu par Kant, Eco, Machiavel, Lévinas, Freud, Kierkegaard, Nietzsche, Hegel... (août-septembre 2009).

${ }^{20}$ Philosophie Magazine. Hors-Série. Évangiles. Saint Paul. Apocalypse. Le Nouveau Testament relu par Arendt, Kant, Nietzsche, Engels, Lacan Sartre, Leibniz... (novembre-décembre 2009).

${ }^{21}$ Le Magazine Littéraire, "La Bible, le Livre des écrivains”, n. 448 (décembre 2005). 


\section{Génesis 4}

Génesis 4, comúnmente conocido como "El relato de Caín y Abel", forma parte de ese conjunto de motivos de la tradición judeo-cristiana constitutivo de los mitos fundacionales de la cultura occidental. Varias expresiones de este relato, como la pregunta: “¿Soy yo guarda de mi hermano?", han llegado a formar parte de ese repertorio selecto de frases memorables de nuestra cultura. Ahora bien, nos interesa aquí no tanto el texto como finalidad en sí, sino más bien la forma en la que este motivo literario ha sido recibido y entendido a lo largo de la historia; o dicho más precisamente, la forma en que la cultura occidental ha ido reconfigurando su comprensión de sí misma a partir de este texto.

Diversos detalles de Gn 4,1-16 sugieren que el núcleo de esta narración fue en otro momento un relato autónomo antes de ser incorporado a su ubicación actual. Las dificultades evidentes en el texto hoy ${ }^{22}$ son resultado parcial de esta incorporación en una unidad mayor (Gn 1-11), que modifica también el sentido último del relato. El texto de Gn 4,1-16 tiene en su forma actual rasgos que permiten ver una conexión a nivel literario y conceptual entre el pecado de Adán y el pecado de Caín. Ambas narraciones han sido editadas siguiendo el mismo esquema procesal: al delito (4,2-8; cf. $3,1-7$ ) sigue la apertura de diligencias por el juez divino ( 4,$9 ; \mathrm{cf} .3,8-10)$; al interrogatorio $(4,9-10$; cf. 3,8-11) sigue la sentencia con la maldición (4,11-12; cf. 3,14-19), cuya ejecución implica el destierro del pecador $(4,16 ; \text { cf. } 3,24)^{23}$.

En un estudio sobre la presencia de este motivo en la literatura alemana, A. Brieger identifica dos momentos en este texto: un momento religioso, que gira en torno al tema del sacrificio, y un momento humano, que gira en torno al tema del fratricidio ${ }^{24}$. Aquí nos concentraremos en el primer momento de este relato. Nos interesa lo que A. Quinones ha llamado "la tragedia de la diferenciación" ${ }^{25}$, esto es: la diferenciación que se hace en el momento del sacrificio y que -de forma arbitraria- muestra preferencia por el sacrificio de Abel. El texto dice: "Pero a Caín y a su

22 L. Ruppert. Genesis. 1. Teilband: Gen 1,1-11,26, Würzburg: Echter Verlag, 1992, 180-188; C. Westermann, Genesis 1-11. A Comentary, Minneapolis: Augsburg Publising House, 198, 282-287; H. SeEbas, Genesis I. Urgeschichte (1,1-11,26), Neukirchen-Vluyn: Neukirchener Verlag, 1996, 144-147.

23 G. Ravası, El libro del Génesis, Barcelona 1994, 118.

24 A. Brieger, Kain und Abel in der deutschen Dichtung, Berlin 1934, 1-2.

25 R. J. Quinones, The Changes of Cain, Princeton 1991, 9. 
ofrenda él [Dios] no miró" (v. 5a). Con esto no se rechazó solo la ofrenda, sino a la persona. Caín se sabe rechazado, indigno de ser mirado por Dios. Y esto se dio antes de la acción de Caín. Como indica Drewermann, quien mató fue alguien que ya había sido rechazado antes de su acción. No se trata de alguien que mató y fue rechazado como consecuencia de ello. El hecho de que el texto no ofrezca ninguna justificación para la "injusticia" divina no puede tener más que un sentido: el redactor no vio necesario dar ninguna razón para ello ${ }^{26}$. John Steinbeck capta el nudo existencial de esta tragedia:

El terror más grande que un niño puede tener es no ser amado. El rechazo es el infierno que le atemoriza. Creo que todo ser humano ha experimentado el rechazo, en un sentido u otro. Y con el rechazo viene el enojo, y, con el enojo, alguna forma de delito en venganza por ese rechazo, y con él, la culpa... Estos dieciséis versículos son una especie de historia de la humanidad en cualquier época, cultura o raza ${ }^{27}$.

Hay al menos dos formas de entender el relato.

1. Podemos concentrarnos en la acción posterior de Caín frente a Abel. En este caso, parece como si esta acción hubiese sido una iniciativa de Caín motivada por una maldad presente en él aun antes del rechazo de su ofrenda. Una especie de naturaleza pecaminosa que era constitutiva de la persona.

2. Podemos concentrarnos, alternativamente, en la acción inicial de Yahvé frente a Caín. La motivación de la conducta de Caín no radica aquí en un rasgo propio de la naturaleza de Caín, sino en una respuesta de situación frente al dolor que le genera un rechazo injustificado o incomprendido a sus ojos. Antes de continuar el desarrollo de esta segunda alternativa, queremos hacer una breve disquisición sobre un punto. La percepción de rechazo que está en la base de todo el relato es problematizada con gran profundidad por la escritora alemana Christine Busta en su poema Abel defiende a Caín: ¿de qué forma se enteró Caín que su sacrificio había sido rechazado por Dios? ¿Escuchó él la voz de Dios o una voz interior? Y si vio una señal, ¿fue correcta su interpretación de la misma? El poema plantea con profundidad este asunto.

Una señal de humo lo ha confundido.

No lo acorraléis. Él se persigue a sí mismo.

No ha comprendido que yo no deseaba

ser nada más que su hermano. No su rival.

26 E. Drewermann, Le Mal. Vol. I, Paris, 1997, 201s.

27 J. Steinbeck, East of Eden, New Ed., New York 2010, capítulo 24/2. 


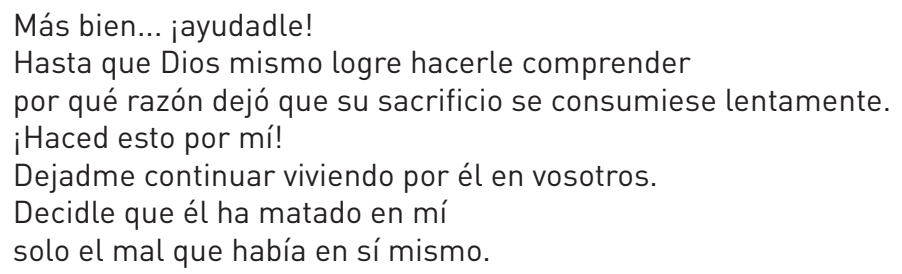

Espero que logre encontrar la paz en un sitio en donde el humo no ascienda más ${ }^{28}$ (traducción propia).

Se puede pensar aquí que la consciencia moral se expresa por el sentido de culpa que acosa a Caín a partir de este momento. Una culpa mayor de lo que él puede soportar. Culpa descrita magistralmente en el poema "La consciencia", de Víctor Hugo.

Volvemos al punto de la comprensión del texto como la acción inicial de Yahvé frente a Caín. Violenta es la perpetración del asesinato. Violenta es igualmente la descalificación de la persona, que envuelve a Caín en una vorágine de celos y agresión. Sobre este relato dirá Erich Fromm:

Con la agresión resultante de la frustración se relaciona la hostilidad producida por la envidia y los celos. La envidia y los celos son frustraciones acentuadas por el hecho de que no solo no consigue una persona lo que desea, sino que en vez de él es favorecida otra persona. La historia de Caín, desamado sin culpa de su parte, que mata al hermano favorecido, y la historia de José y sus hermanos, son versiones clásicas de celos y envidia ${ }^{29}$.

Planteada dentro de este marco, la narración tiene otras posibilidades de lectura. Nos interesa de modo particular la actitud de la persona frente a la autoridad, $o$, dicho en otras palabras, la respuesta humana frente a formas de desigualdad justificadas a partir del binomio autoridad/sumisión. Lo que está en juego en el fondo de este texto es, nos parece, la postura del ser humano frente a la injusticia. La atención de este texto se ha concentrado en la acción de Caín, porque previamente no era "políticamente correcto" poner la figura de Yahvé en el banquillo de los acusados. Con la obra de Byron Caín, este se convierte en símbolo de la rebelión e imagen de la emancipación humana.

La búsqueda de la razón para el rechazo de la ofrenda de Caín ha sido la "cruz" de los comentaristas, aun cuando la preferencia por el hermano menor

${ }^{28}$ C. Busta, “Abel verteidigt Kain”, en G. LANGENHORSt, Gedichte zur Bibel, München 2001, 55.

29 E. Fromm, El corazón del hombre. Su potencia para el bien y para el mal, México ${ }^{9} 1985,17$. 
es un hecho común en Génesis. La soberanía de la divinidad en sus decisiones es una premisa que se da por sentada en el ámbito de las religiones del antiguo Cercano Oriente y también en Israel: "Hago gracia a quien hago gracia y tengo misericordia con quien tengo misericordia" (Ex 33,19; cf. Job 9,12-15).

La ausencia de una razón para la decisión divina en este relato no necesita, a nuestro criterio, una explicación. Esta ausencia es programática en el relato. La "falta de Caín" no radica en un error litúrgico ni en una falta de interés, como se ha supuesto reiteradamente. Su "falta" radica en no haber aceptado la voluntad divina, en no haber sabido resignarse. Esta actitud frente a la autoridad "parte las aguas" entre la tradición judeo-cristiana, por una parte, y la moderna tradición intelectual de Occidente, por otra, tradición en la cual el héroe cultural griego Prometeo es fundamental. Esta segunda tradición es heredera de la cultura greco-romana, del Renacimiento y de la Ilustración. La sociedad moderna no puede entender más la justicia como un favor, sino como un derecho. Y esta premisa se aplica igualmente para la figura divina. Entre las facultades de la divinidad no está más la de ser arbitrario. No al menos en el mundo moderno.

Las referencias a Caín en el Nuevo Testamento (Heb 11,4; 1 Jn 3,12) se hacen eco de la comprensión que se había afianzado en el judaísmo helenista y que perduraría por siglos: Caín asesina a Abel movido por su maldad. Aun antes de que Caín matara a Abel había algo malo en él a ojos de Dios. Caín no era malo porque asesinó a su hermano, sino precisamente lo contrario: asesinó a su hermano porque era malo (1 Jn 3,12b). Orígenes de Alejandría afirma: "La maldad de Caín no comienza cuando mata a su hermano. Ya desde antes, Dios, que conoce los corazones, había ignorado a Caín y su sacrificio; pero la maldad y bajeza de este se hicieron evidentes cuando él mató a su hermano" ${ }^{30}$. La tradición rabínica explica el hecho recurriendo a la noción de un impulso malvado presente en la naturaleza de Caín (el yetzer ha ra'a de la teología rabínica ${ }^{31}$ ).

Nuestro acercamiento no explora las razones que habría podido tener la figura divina para rechazar el sacrificio de Caín, porque nos parece que este silencio es parte del relato. La razón de este silencio no es uno de esos detalles que "se ha perdido" en la larga historia de este texto. La "arbitrariedad" de un poder incuestionable es, precisamente, la causa que moviliza en Caín la voluntad para la rebelión. Es la acción de Yahvé la que crea las condiciones y engendra el acto decisivo por parte de Caín.

${ }^{30}$ A. Louth - M. Contı (eds.), Genesis 1-11 (Ancient Christian Commentary on Scripture. Old Testament I), Downers Grove (IL) 2001, 104.

31 H. Strack - P. Billerbeck, Kommentar zum Neuen Testament aus Talmud und Midrash, Band IV.1, München 1922, 466-483: “Der gute und der bose Trieb". 


\section{Caín en la literatura del siglo xIX}

Es necesario “" destacar el creciente interés en el personaje de Caín en el siglo XIX. A continuación ofrecemos algunas de las obras que tratan el tema en el siglo que va de 1821 a 1921:

1821, George G. Byron
1822, William Blake
1837, Friedrich Rückert
1844, Gérard de Nerval
1844, Frederik Paludan-Müller
1851, Franz Hedrich
1857, Charles de Baudelaire
1859, Victor Hugo
1862, Leconte de Lisle
1865, Adolf Böttger
1866, Leopold von Sacher-Masoch
1880, Gustav Kastropp
1888, Wilkie Collins
1888, Adalbert von Hanstein
1895, Martin Wagener
1896, Ludwig Weber
1896, Paul Viktor Wichman
1897, Henriette Laudien
1899, Eduard von Meyer
1904, Karl August Porges
1904, Paul Heyse
1904, Karl August Porges
1906, Luise Westkirch
1906, Oliver F. Emerson
1908, Otto Borngräber
1909, Hilde Domin
1909, Paul L. Fuhrmann
1909, Helge Rode
1911, Johannes Tralow
1912, Jon Norstog
1912, Martin Frehsee
1913, Else Lasker-Schüler
1917, Miguel de Unamuno
1917, Friedrich Koffka
1920, Anton Wildgans
1921, Bernard Shaw
1921, Walther Unus

Cain, a Mystery (play)

The Ghost of Abel

Kain und Habil (Gedicht)

Voyage en Orient (conte "Adoniram")

Abels $D \phi d$

Kain, Dramatisches Gedicht in drei Acten

Les fleurs du mal (poème "Abel et Caïn")

La légende des siècles (poème "La conscience")

Poèmes barbares (poème "Qaïn")

Die Tochter des Kain (Dichtung)

Das Vermächtnis Kains (Roman)

Kain (Roman)

The Legacy of Cain

Kains Geschlecht (Gedicht)

Kains Tod (Drama)

Kain, ein Drama in 5 Akten und ein Vorspiel

Kain, Trauerspiel

Kains Ende, Epische Dichtung

Die Bücher Kains vom ewigen Leben

Kain (Drama)

Kain

Kain. Ein Drama in drei Aufzügen

Kains Entsühnung (Roman)

Legends of Cain

Die ersten Menschen. Erotisches Mysterium

Abel, steh auf (Gedicht)

Kain. Tragödie in drei Aufzügen

Kain og Abel, akuespil i en akt

Kain. Der Heiland (Roman)

Kain, eit dramatisk dikt

Kain (Drama)

Hebräische Balladen (Gedicht "Abel")

Abel Sánchez, historia de una pasión (novela)

Kain, ein Drama

Kain (Roman)

Back to Methuselah (Epic "In the Garden of Eden").

Kain und Abel, ein Gedicht 
Esta lista, que justifica la calificación de Caín como "mito literario de origen bíblico" 32 , incluye solo aquellas obras dedicadas explícitamente a este personaje. Dejamos de lado aquellas otras en las que encontramos "influencias" o "alusiones" al personaje; así como la presencia del motivo (no del personaje) en otras obras de este período, como es el caso del Konrad Wallenrod, del escritor polaco Adam Mickiewicz (1828); Les chants de Maldoror, del escritor uruguayo-francés Comte de Lautréamont (1869); Le désespéré, del novelista francés Léon Bloy (1886), y el relato corto de Joseph Conrad The Secret Sharer (1912), entre otros. Frente a este hecho surge una pregunta obvia: ¿de dónde nace este interés por el personaje? ¿Por qué en este momento en particular?

\section{El Caín de Byron: imagen de la Modernidad}

La lista mencionada se inicia con George G. Byron porque consideramos que esta es una obra seminal. El personaje deja de enmarcarse dentro de la disyuntiva "bueno/malo". Lucifer emerge como una especie de desdoblamiento de la consciencia del mismo Caín, permitiéndole a este dialogar sobre su existencia y la naturaleza del mal. El pecado no se vincula ya tanto con la muerte de Abel cuanto con el hecho mismo de la rebelión. Caín piensa. Caín desea saber. En esto radica en última instancia su "pecado". El Caín de Byron se nos presenta como una existencia consciente. No se contenta con la actitud sumisa y pasiva de Abel. Caín adquiere la profundidad y complejidad propia de los personajes del romanticismo. “¿Enséñame el misterio de mi ser!”, dirá Caín a Lucifer ${ }^{33}$.

Esta forma de pensar autónoma conduce a Caín a la consciencia de su libertad. No puede aceptar ya, sin más, las imposiciones arbitrarias del "Omnipotente tirano". Se rebela contra una injusticia evidente. Ese es realmente su crimen. Lucifer, más que el Satanás que encontraremos en las páginas del Nuevo Testamento, es una especie de literarisches Dasein que, cumpliendo una función socrática, insta a Caín a descubrir en su propio interior el valor de la razón. El hecho de que Dios sea todopoderoso no convierte en necesariamente buenas sus decisiones. No lo son cuando estas

32 Expresión de P. Sellier, La Bible. Aux sources de la culture occidentale, Paris $2007,332$.

33 Let me but be taught the mystery of my being. 
decisiones van en contra de la razón humana. En tales instancias, el ser humano está llamado a desafiar a ese Tirano infinito ${ }^{34}$.

Ahora bien, analizando las influencias formativas de esta obra, el Caín de Byron (1821) acusa la impronta del Prometeo de J. W. Goethe, poema escrito unos cincuenta años antes (1773), y en donde la figura titánica de este personaje mítico afirma la razón y la liberación humanas en su desafío a la figura del todopoderoso Zeus. A continuación, el inicio del poema:

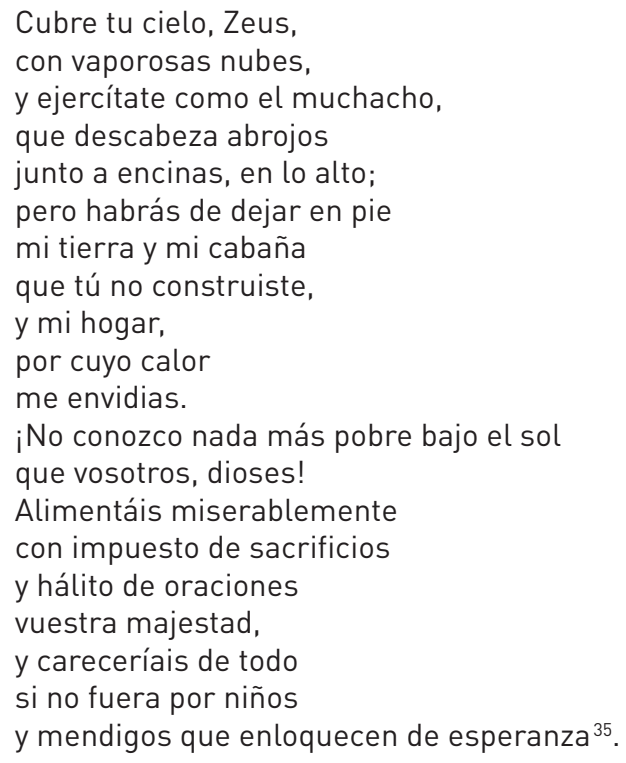

Ambas obras tienen importantes aspectos en común, como la afirmación de la autonomía del ser humano frente al poder divino. En ambas, la imagen de Dios como figura de autoridad que concentra poder y razón se desvanece. El personaje Lucifer en la obra de Byron dirá de Dios:

¡Dejémosle sentado allá, en su vasto y solitario trono, creando mundos, intentando hacer

la eternidad algo menos gravosa a su inmensa existencia y a su soledad siempre incompartible! ¡Dejemos que acumule orbe tras orbe, a solas, el tirano insoluble e infinito!

Si fuera a destruirse a sí mismo sería

34 Byron emplea explícitamente este tipo de lenguaje: "The Omnipotent tyrant", "indisoluble tyrant", "the proud One", "the Destroyer [...] the Maker".

35 Traducción en V. CAstillo Morquecho, "Ciencia y ser: paradoja e ironía en el Prometheus goetheano", Asclepio 65 (2013/1), 3. 
el regalo mejor que nos hiciera nunca.

Dejémosle reinar, multiplicarse

en la desdicha. Al menos, espíritus y hombres

nos comprendemos, y sufriendo juntos

nuestros padecimientos, que son innumerables,

se hacen más llevaderos... ${ }^{36}$

En diálogo con Caín, Lucifer le confronta con las siguientes palabras:

Yo no he tentado a nadie, salvo con la verdad...

¿No era el árbol del conocimiento?

¿No rebosaba frutos el árbol de la vida?

¿Acaso yo le dije que comiera de ellos?

¿Fui yo quien plantó cosas prohibidas al alcance

de seres inocentes y curiosos

por su propia inocencia?

Yo os habría hecho dioses;

e incluso aquel que os expulsó lo hizo

para que "no comierais del árbol de la vida,

convirtiéndoos en dioses como yo".

¿No fueron esas sus palabras? ${ }^{37}$

Caín se contrapone a la sumisión encarnada por los otros personajes de la obra. Recordemos que, según Aristóteles, entre las medidas que garantizan la perpetuación de la tiranía se encontraba la de "eliminar a los hombres sobresalientes" y "mantener una vigilancia estrecha sobre todas aquellas cosas que habitualmente engendran el valor y la confianza" entre las personas ${ }^{38}$. Y son estos rasgos precisamente los que Dios, ese "Tirano omnipotente", trata de impedir en los humanos:

[Lucifer:] Seres mucho más altos que vosotros

son esclavos, lo mismo que lo son

otros más altos que ellos,

por no preferir una independencia

torturada a las dulces agonías de alabanzas con arpas

y cantos y oraciones egoístas

al que es omnipotente solo porque lo es; no por amor,

sino por beneficio y por terror...

[Ada, hija de Adán:] ¡Oh, madre!..

Somos atormentados por demonios

que usurpan las palabras de Yahvé,

tentándonos con nuestras propias ideas

36 L. Byron, Caín. Traducción de J. L. Piquero, Sevilla 2011, 45.

37 Ib., 45.

38 R. M. Hutchins, The Works of Aristotle, Vol. II, Chicago 1984, 516. La cita corresponde a la Política V.11.1313b. 


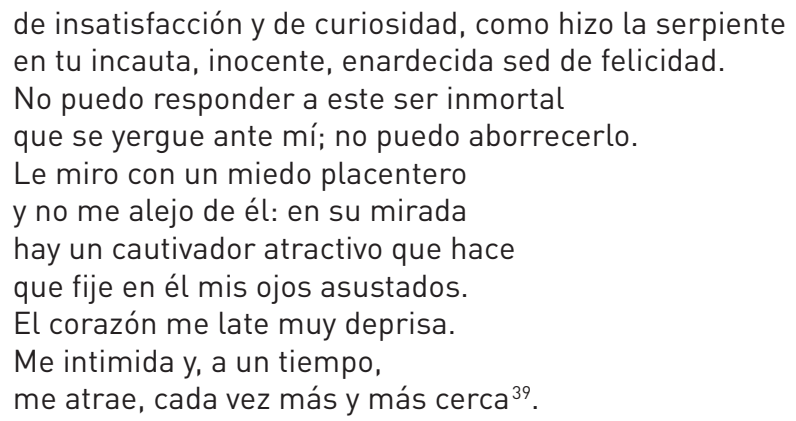

\section{Caín: símbolo de la rebelión ilustrada}

Dos hechos fundamentales del siglo XVIII son claves para entender la transformación que experimenta la figura de Caín durante el siglo XIX: la Revolución francesa y la publicación de la Encyclopédie de d'Alembert y Diderot. La primera redefine las coordenadas históricas y políticas que enmarcan al ser humano; la segunda redefine las coordenadas intelectuales a partir de las cuales persona y cultura se posicionan frente a la religión. Nociones clave como las de autoridad y obediencia van a redefinirse a partir de estos dos hechos. El empleo de símbolos tomados de la Biblia justifica la monarquía absoluta a partir del derecho divino. Bossuet afirma en su Politique tirée des propres paroles de l'Écriture sainte (1709):

Dios establece a los reyes como sus ministros y gobierna por medio de ellos a los pueblos [...] Toda persona debe obedecer a los príncipes por razón de su religión y su conciencia [...] El gobernante no necesita dar a nadie razón por aquellas cosas que ordena [...] No puede existir ninguna fuerza coactiva en contra del gobernante ${ }^{40}$.

Estas ideas, que fundamentan la teoría política del absolutismo, fueron propuestas y defendidas a partir de textos bíblicos. La superación de esta forma de gobierno implicó la crítica correspondiente de las categorías religiosas que la sustentaban. Presuponía el derecho a la insurrección, como lo sostuvo L. A. de Saint-Just, uno de los ideólogos de la Revolución francesa: "Allí donde un hombre obedece algo que no considera bueno, no hay libertad. La ley no es otra cosa que la voluntad de aquel que la impone.

39 Ib., $64 \mathrm{~s}$.

40 J.-B. Bossuet, "Politics drawn from the very words of the Holy Scripture", en M. Perri, Sources of the Western Tradition. II. From the Renaissance to the Present, Boston (MA) 2015, 18-19. 
Por ello, toda persona tiene el derecho de resistir leyes opresivas. Las insurrecciones que han tenido lugar bajo el despotismo han sido siempre saludables" ${ }^{41}$. La insurrección se ve en este contexto como una forma de afirmación del ser humano, como la expresión de un cierto humanismo. Por ello, tal insurrección debe ser total, y envuelve a la persona, igualmente de forma total. Solo rechazando toda forma de tiranía se podría "alcanzar la luz", expresión de evidentes tintes religiosos utilizada frecuentemente en los escritos de la época.

Cabe mencionar a este respecto dos hechos significativos. Primero, la publicación en 1715 de la comedia La estatua de Prometeo, de Calderón de la Barca, considerada la obra más importante dedicada a este mito desde Esquilo. En ella, el conocimiento devuelve la confianza al ser humano, en el ser humano. En la "Segunda jornada" de esta obra encontramos el siguiente diálogo acerca de la vivificación de la estatua de Prometeo: [Epimeteo pregunta:] “¿Qué es lo que miro! ¿Quién, dioses, nuevo espíritu le inflama, nuevo aliento y nueva vida?" [El coro de músicos responde:] "Quien da ciencia, da voz al barro y luz al alma" ${ }^{42}$. Esta última frase que destacamos lo explica todo: dotar de conocimiento es un hecho que emula la acción de Dios al dotar de vida a la estatua de barro, insuflándole el espíritu. Dotar de conocimiento es dar luz al alma.

En segundo lugar debemos mencionar la ilustración de portada de la Encyclopédie de Diderot y d'Alembert (obra del artista francés CharlesNicolas Cochin), por su estrecha semejanza con imágenes tradicionales de la Trinidad, propias del arte católico. Solo que en la Encyclopédie lo que encontramos como figura central no es la imagen de Cristo, sino la imagen de la Verdad rodeada por una luz brillante. Las figuras que la acompañan son la Razón y la Filosofía, que rasgan el velo que cubre la Verdad (¡!). Así, las figuras tradicionales del Padre, el Hijo y el Espíritu Santo han sido sustituidas por la Trinidad de la perfectibilidad del "Hombre", el conocimiento y la razón ${ }^{43}$. Puede decirse que lo que presenciamos en esta época no es, en sentido estricto, una eliminación de símbolos religiosos cuanto una resignificación de los mismos.

41 M. Charpentier - J. Charpentier, Littérature. Textes et Documents. XVIII siècle, Paris $1987,467$.

42 P. Calderón de la Barca, Comedias del célebre poeta español Pedro Calderón de la Barca, Madrid 1715; la cita está tomada de la comedia "La estatua de Prometo" (179-229), 196.

43 P. Brunel, Companion to Literary Myths, Heroes and Archetypes, London - New York 1992, 979. 


\section{Caín: Nerval y Baudelaire}

Gérard de Nerval incluye en su obra Voyage en Orient (1851) un relato en el que Caín aparece como símbolo de la afirmación del ser individual contra Dios. En el fragmento que citamos, Adoniram, el último de los descendientes de Caín, es escoltado por Tubal-Caín al santuario de fuego en un reino subterráneo. Allí ambos tienen un diálogo en el que Caín muestra cómo la suya fue una vida de amargura, marcada por la ingratitud y la injusticia. En el texto palpita el rechazo a la autoridad tiránica. He aquí el diálogo:

[Caín saludando a Adoniram:] ¡Hijo mío! He puesto al servicio de hombres ignorantes y débiles el espíritu de genios que reside en mí. Yo he arrullado la infancia de Abel... al que ellos llaman mi hermano. Antes de traer la muerte a la tierra, yo había experimentado la ingratitud, la injusticia y las amarguras que corroen el corazón. Trabajaba sin cesar, arrancándole nuestro alimento a un suelo avaro. Inventando para el bienestar de los humanos estos arados que presionan la tierra para producir, haciendo renacer para ellos, en el seno de la abundancia, ese Edén que ellos habían perdido. Por lograrlo, jyo hice de mi vida un sacrificio!

Y en el colmo de la iniquidad, ¡Adán no me amó! Eva recordaba haber sido arrojada del paraíso por haberme traído al mundo. En su corazón, cerrado por el interés, todo era para su Abel. Él, arrogante y mimado, me considerada como el sirviente de todos. Adonai estaba con él, ¿qué más le hacía falta? Y así, mientras yo con los sudores de mi frente regaba la tierra, tierra de la que Abel se sentía rey, él mismo, ocioso y consentido, apacentaba sus rebaños dormitando bajo los sicomoros.

Yo me quejaba, y nuestros padres invocaban la equidad de Dios. Le ofrecíamos sacrificios, y el mío, de gavillas de trigo que yo mismo había cultivado -¡las primicias del verano!-, el mío lo rechazó con desprecio... Es así como este Dios celoso ha rechazado siempre el genio inventivo y fecundo, y ha dado el poder y los derechos de opresión a los espíritus vulgares. El resto tú lo conoces...

Yo apagué la llama de Abel... Adonai no me perdonó nunca. Convirtió en un crimen imperdonable haber quebrado un vaso de barro. ¡Él, que en las aguas del diluvio había ahogado a millones de personas! ¡Él, que por diezmarlos les ha suscitado tantos tiranos! 44 (traducción propia).

El poema de Baudelaire "Abel et Caïn" (1857), escrito pocos años después de la obra de Nerval, acusa el sentido de arbitrariedad del poder divino. Una fuerza ciega e injusta determina destinos sin atención alguna a los méritos personales. A continuación, unos fragmentos del poema:

${ }^{44}$ G. DE NerVal, Voyage en Orient, Tome II, Paris 1851, 450. 
Raza de Abel, tú come y duerme;

Dios te sonríe complaciente.

Raza de Caín, en el fango

cae y muere míseramente.

Raza de Abel, tu sacrificio

¡es aroma de serafín!

Raza de Caín, tu suplicio

¿podrá tener un día su fin?

Raza de Abel, mira tus siembras

y tus rebaños prosperar.

Raza de Caín, oigo que el hambre

igual que a un perro te hace aullar.

Raza de Abel, patriarcalmente

conforta el vientre junto al lar.

¡Raza de Caín, en tu negro antro

tiembla de frío, pobre chacal! 45

\section{Caín: Unamuno y Brender}

En el siglo xx, el tema da un giro subjetivo. La desigualdad en el trato corroe el alma humana y conduce inexorablemente a la envidia entre los hermanos. Esta dimensión subjetiva del problema la plantea, bajo la influencia del existencialismo, Miguel de Unamuno en su novela Abel Sánchez, de la que citamos algunos párrafos:

No recordaban Abel Sánchez y Joaquín Monegro desde cuándo se conocían. Eran conocidos desde antes de la niñez, desde su primera infancia, pues sus dos sendas nodrizas se juntaban y los juntaban cuando aún ellos no sabían hablar. Aprendió cada uno de ellos a conocerse conociendo al otro. Y así vivieron y se hicieron juntos amigos desde el nacimiento, casi más bien hermanos de crianza. En sus paseos, en sus juegos, en sus otras amistades comunes parecía dominar e iniciarlo todo Joaquín, el más voluntarioso; pero era Abel quien, pareciendo ceder, hacía la suya siempre. Y es que le importaba más no obedecer que mandar. Casi nunca reñían. “¡Por mi lado, como tú quieras!”, le decía Abel a Joaquín, y este se exasperaba a las veces porque con aquel “ ¡como tú quieras!” esquivaba las disputas. Un día, al jugar con otros niños del barrio, en medio de una disputa, Joaquín le gritó: “Eso no vale. ¡O con él o conmigo!... Y todos se fueron con Abel, dejando a Joaquín solo. Al comentar este en su Confesión tal suceso de la infancia, escribía: "Ya desde entonces era él el simpático, no sabía por qué, y antipático yo, sin saber por qué, y me dejaban solo. Desde niño me aislaron mis amigos... Abel era el que hacía reír con sus gracias... Joaquín es mucho más

45 Ch. Baudelaire, Les fleurs du mal, Paris 1857, 219-221. Traducción española de A. LÁZARo, Biblioteca Virtual Universal: http://www.biblioteca.org.ar/libros/152815. pdf. [consulta: 2/5/2016]. 
aplicado, pero Abel es más listo... Y este juicio común de los compañeros, sabido por Joaquín, no hacía sino envenenarle el corazón ${ }^{46}$.

Empecé a odiar a Abel con toda mi alma y a proponerme a la vez ocultar ese odio, abonarlo, criarlo, cuidarlo en lo recóndito de las entrañas de mi alma. ¿Odio? Aún no quería darle su nombre ni quería reconocer que nací, predestinado, con su masa y su semilla. Aquella noche nací al infierno de mi vida ${ }^{47}$.

Mi vida... ha sido un arder continuo, pero no la habría cambiado por la de otro. He odiado como nadie, como ningún otro he sabido odiar, pero es que he sentido más que los otros la suprema injusticia de los cariños del mundo y de los favores de la fortuna. No, no, aquello que hicieron conmigo... No fue humano ni noble; fue infame; pero fue peor, mucho peor, lo que me hicieron todos, todos los que encontré desde que, niño aún y lleno de confianza, busqué el apoyo y el amor de mis semejantes. ¿Por qué me rechazaban? ¿Por qué me acogían fríamente y como obligados a ello? ¿Por qué preferían al ligero, al inconstante, al egoísta? Todos, todos me amargaron la vida. Y comprendí que el mundo es naturalmente injusto y que yo no había nacido entre los míos. Esta fue mi desgracia, no haber nacido entre los míos ${ }^{48}$.

Una variante de este motivo lo encontramos en el relato "Conflicto fraternal", de la escritora alemana Irmela Brender, que traducimos a continuación:

Abel era un pastor; pero Caín era un hombre de campo. Caín era el hermano mayor, era serio y recatado. Sus padres tenían muchas expectativas con respecto a él. El sería... él debía... él podría... Con él aprendieron ellos a ser padres. Muchas veces estaban ellos inseguros, y se volvían entonces estrictos. En el fondo deseaban quizá ser justos, pero no siempre lo lograban; en parte porque tenían tantas expectativas acerca de él, en parte porque esperaban tanto de él.

Entonces nació Abel. Y él se convirtió siempre, por así decir, en “el pequeño". Cuando él despedazaba los juguetes de Caín, Caín no podía hacer nada, porque Abel era "el pequeño". Se es indulgente con los pequeños. Se ríe siempre con sus gracias.

Caín había sido el único, pero, cuando Abel nació, él fue destronado de este puesto. Él era, simplemente, el hermano mayor. Su madre no tenía ya más tiempo disponible para escucharle, porque tenía que alimentar a Abel, porque Abel lloraba, porque Abel reía. Sencillamente, porque Abel estaba allí.

Caín aprendió entonces que la vida es difícil e injusta. Él se convirtió en un hombre de campo, en un agricultor. Al final tenía su espalda jorobada del trabajo. Él fue campesino en una época en la que no existían aún tractores ni las cortadoras mecánicas. Cultivaba los tubérculos con sus manos desnudas, plantó el maíz y vio cómo el granizo destruía ambas.

46 M. de Unamuno, Abel Sánchez. Historia de una pasión, Madrid 1917, 9-11.

47 Ib., 33-34.

48 lb., 193-194. 
Abel aprendió que la vida era algo divertido. Se hizo pastor, paseaba sus ovejas sobre los prados, tocaba la flauta. Cuando estas pastaban, él solo debía observar que ninguna se perdiera... y casi nunca perdió alguna.

Sucedió que, pasado un tiempo, Caín trajo al Señor una ofenda de los frutos del campo, y Abel trajo también de las primicias de su rebaño. El Señor vio con agrado a Abel y su ofrenda, pero no vio con agrado a Caín ni su ofrenda.

Caín había cosechado unas gruesas y hermosas zanahorias y un maíz dorado como el oro. Orgulloso, mostró a los otros el fruto de su trabajo, pero los otros se rieron de él. Caín sabía bien lo que ellos pensaban: las zanahorias gruesas son duras y solo sirven para alimentar animales. Y el maíz, jay Dios!, cuál es el mérito de eso, si basta que llueva un poco y haga sol para que cualquiera coseche maíz. ¡Gran ofrenda es esa!

En el rebaño de Abel nacieron un par de corderos y él los alimentó. Los corderitos son encantadores, tan pequeños y frágiles sobre sus débiles patas, tan indefensos y dulces. Todos elogiaban a Abel, y Abel se sentía feliz.

Entonces habló Caín con su hermano Abel. “Abel -dijo Caín-, no es que yo no aprecie tus corderos, son encantadores. Pero mis zanahorias y mi maíz... ¡Me he esforzado tanto por esto! He trabajo por esto desde el amanecer hasta la hora de la cena. Siempre ha sido así. He debido esforzarme por todo; en cambio, a ti las cosas parecen caerte siempre del cielo. Solamente porque tú has sido siempre "el pequeño", el más débil, el más joven. ¿Por qué nunca dices nada acerca de esto?..." Abel no respondió.

“Una vez, cuando éramos niños -dijo Caín-, recogimos los dos flores del campo para nuestra madre. Yo traía mis brazos llenos de margaritas para ella, y tú solo un cardo. A ti te abrazó y te besó, porque tú eras 'el pequeño'. Solo por eso valió mucho más tu cardo que todas mis flores. Eso ya no puede cambiarse. Pero tú, tú, Abel, no puedes sentarte ahí siempre y permitir que tú recibas siempre la dicha y yo solo el esfuerzo. ¿Por qué, por qué no dices nada?" Abel empezó a tocar la flauta.

Y sucedió que, cuando estaban en el campo, Caín se levantó y mató a su hermano Abel.

Caín sabía que él era culpable. Él escuchaba solamente el eco de sus propias palabras, él era culpable.

El Señor dijo: “Qué has hecho? La sangre de tu hermano clama a mí desde la tierra".

Caín dijo entonces algo más; él pensó: “ ¿Solamente ahora? ¿Por qué clama la sangre de mi hermano solamente ahora? ¿Por qué no clamó él nunca antes?", y Caín rompió la flauta ${ }^{49}$ (traducción propia).

49 I. Brender, “Geschwisterstreit”, en F. W. NiehL, Bibel Verstehen. Zugänge und Auslegungswege. Impulse für die Praxis del Bibelarbeit, München 2006, 192-194. 


\section{El Caín de Saramago: la individualidad que prescinde de toda autoridad}

El leitmotif de la rebeldía contra la autoridad planteado a mediados del siglo XIX por el Caín de Byron será desarrollado a mediados del siglo Xx en la obra L'homme revolté, de Albert Camus (1951), y a inicios del XXI en el Caim de José Saramago (2009). En razón del género propio de cada una de estas dos obras presentaremos primero la novela de Saramago. A continuación, un importante diálogo entre Dios y Caín:

“¿Qué has hecho con tu hermano?”, preguntó.

Y Caín respondió con otra pregunta: “¿Soy yo acaso el guardaespaldas de mi hermano?"

"Lo has matado".

"Así es, pero el primer culpable eres tú, yo habría dado mi vida por su vida si tú no hubieses destruido la mía".

"Quise ponerte a prueba".

“¿Y quién eres para poner a prueba lo que tú mismo has creado".

"Soy el dueño soberano de todas las cosas".

"Y de todos los seres, dirás, pero no de mi persona ni de mi libertad".

"Libertad para matar".

“Como tú fuiste libre para dejar que matara a Abel cuando estaba en tus manos evitarlo, habría bastado que durante un momento abandonaras la soberbia de la infalibilidad que compartes con todos los demás dioses, habría bastado que por un momento fueses de verdad misericordioso, que aceptases mi ofrenda con humildad, simplemente porque no deberías rechazarla, porque los dioses, y tú como todos los otros, tenéis deberes para con aquellos a quienes decís que habéis creado".

"Ese discurso es sedicioso".

“Es posible que lo sea, pero te garantizo que, si yo fuese dios, diría todos los días: 'Benditos sean los que eligieron la sedición, porque de ellos será el reino de la tierra'".

"Sacrilegio".

“Lo será, pero en cualquier caso nunca mayor que el tuyo, que permitiste que Abel muriera".

"Tú has sido quien lo ha matado". por ti”.

“Sí, es verdad, yo fui el brazo ejecutor, pero la sentencia fue dictada

“La sangre que está ahí no la derramé yo. Caín podía haber elegido entre el bien y el mal, si eligió el mal pagará por eso".

"Tan ladrón es el que va a la viña como el que se queda vigilando al guarda", dijo Caín.

"Y esa sangre reclama venganza”, insistió Dios.

"Si es así, te vengarás al mismo tiempo de una muerte real y de otra que no ha llegado a producirse".

"Explícate". 
"No te va a gustar lo que vas a oír".

"Que eso no te importe, habla".

“Es muy sencillo, maté a Abel porque no podía matarte a ti, pero en mi intención estás muerto" 50 .

En relación con esta lectura de Saramago vale la pena traer a colación la edición de Varsovia de un antiguo midrás del Génesis $\left(\right.$ Tanhuma $\left.^{51}\right)$. Dos aspectos de su argumentación en este diálogo tocan elementos presentes ya en dicho midrás, obra que Saramago muy probablemente haya conocido.

En el v. 5 dice el midrás:

Caín dijo: “Sí, yo lo maté. Tú creaste en mí una inclinación maligna. Se supone que tú guardas de todos, pero tú has permitido que yo lo mate. Tú, pues, lo has matado. Tú, que eres llamado Anokhi (= yo). Si tú hubieras aceptado mi ofrenda del mismo modo en que aceptaste la suya, yo no habría tenido celos de él" 52 .

\section{Duman comenta:}

La última línea de esta sección añade la acusación de que es el mismo rechazo de Caín por parte de Dios lo que causa la muerte. A diferencia de otras fuentes, que mencionan un argumento similar, Tanhuma no intenta subestimar estos reclamos. Al parecer, los editores de este midrás encontraron este aspecto de la historia particularmente persuasivo y encontraron la forma de expresar por medio de él sus propias reservas respecto a la gracia divina ${ }^{53}$.

En relación con el clamor de la sangre de Abel en el v. 10, el midrás muestra a Caín esgrimiendo contra Yahvé:

Por ejemplo, si dos hombres pelean y uno mata a otro mientras un tercero contempla sin intervenir, ¿a quién se debe culpar sino al observador? Por esta razón debemos entender la frase "la sangre de tu hermano está clamando a mí" como "la sangre de tu hermano está clamando contra mí".

\section{Duman comenta:}

De nuevo Caín lanza dudas sobre la gracia de Dios e implica la negligencia de Dios en el crimen de Abel. El tema del espectador que contempla impa-

50 J. Saramago, Caín. Traducción de P. del Río, Madrid 2010. Como es conocido, Saramago publica sin puntuación. Nosotros la hemos agregado para no dificultar la lectura. No se indica número de página porque se ha utilizado la edición electrónica.

51 Cf. V. Armenteros de la Cruz, Midrás Tanhuma Génesis, Estella 2010, para aspectos introductorios sobre este midrás.

52 J. Duman, "The Treatment of the Cain and Abel story in Midrash Tanhuma", Mo'ed 17 (2007) 1-28. La versión citada es la provista por Duman en su artículo.

$53 \mathrm{lb} ., 18$. 
sible sin hacer nada por impedir la tragedia emerge como central. En el contexto de una cultura como la actual, el observador negligente puede recibir mayor atención pública o responsabilidad que el mismo perpetrador ${ }^{54}$.

\section{Camus: la herencia de los hijos de Caín}

La Universidad de Chicago patrocinó a mediados del siglo pasado un importante proyecto editorial llamado The Great Books of the Western World. Esta era originalmente una colección de 54 volúmenes que contenían las obras clásicas en ciencia, historia, filosofía, literatura y política desde Homero a Freud ${ }^{55}$. En dos volúmenes iniciales, el filósofo Mortimer J. Adler redacta The Great Ideas. A Syntopicon of Great Books of the Western World, selección de lo que el equipo editorial consideró que eran las cincuenta ideas matrices de la tradición intelectual de Occidente ${ }^{56}$. Entre estas ideas se encuentran las de tiranía, oposición, revolución, democracia, libertad, voluntad, honor y hombre. Es claro que la historia, desde el Renacimiento hasta la fecha, está marcada por luchas sociales que han girado en torno a la superación de formas tiránicas de poder, la afirmación de la individualidad y libertad humanas, y las nociones de derecho y razón. El Renacimiento, la Reforma, la Ilustración, el romanticismo y la Revolución industrial no son sino ejemplos y productos de esto. Las grandes obras de los últimos siglos dan forma a estas ideas.

Resultaba inevitable que el Ancient Régime, cuyas ideas religiosas estaban marcadas por los principios de autoridad y obediencia, entrara en contradicción con las ideas de la Ilustración. La figura de Voltaire ejemplifica esta tensión. Como bien mostrará Albert Camus en su estudio fundamental sobre la rebelión en la cultura occidental, el relato de Caín juega un papel clave en este debate. La figura de este Dios concentraba en sí mismo los rasgos de un poder absoluto y despótico. En palabras de Camus: "Es la noción del dios personal, creador, y por lo tanto responsable de todas las cosas, la que da, por sí misma, sentido a la protesta humana" ${ }^{57}$.

54 Ib., 19.

55 Actualmente la obra consta de 60 volúmenes; en ella se han incluido las obras de autores como Kierkegaard, Dickens, Einstein, Heidegger, Max Weber, Lévi-Strauss, etc.

${ }^{56}$ R. M. Hutchins (ed.), Great Books of the Western World. The Great Ideas: I-II, Chicago 1984.

57 A. Camus, L'homme revolté, Paris 1951, 46 (traducción propia). 
Caín se convierte así en el héroe romántico por excelencia. Camus esboza de la siguiente manera "La herencia de los hijos de Caín":

Un esclavo que ha recibido órdenes durante toda su vida juzga de pronto inaceptable una nueva orden. ¿Cuál es el contenido de ese "no"? Significa, por ejemplo, "las cosas han durado demasiado", "hasta ahora sí, en adelante no", "vais demasiado lejos", y también "hay un límite que no pasaréis". En suma, ese "no" afirma la existencia de una frontera... Así, el movimiento de rebelión se apoya, al mismo tiempo, en el rechazo categórico de una intrusión juzgada intolerable y en la certidumbre confusa de un derecho. Más exactamente, en la impresión del rebelde de que "tiene derecho a..." La rebelión va acompañada de tener uno mismo, de alguna manera y en alguna parte, razón. En esto es en lo que el esclavo rebelado dice al mismo tiempo sí y no... De cierta manera opone al orden que le oprime una especie de derecho a no ser oprimido más allá de lo que puede admitir ${ }^{58}$.

El esclavo rebelde afirma que en él hay algo que no acepta la manera como le trata su amo. [...] El esclavo alzado contra su amo no se preocupa, advirtámoslo, de negar a ese amo como ser. Le niega como amo ${ }^{59}$.

La rebelión metafísica propiamente dicha no aparece de una manera coherente en la historia de las ideas hasta fines del siglo xvIII. Los tiempos modernos se inician entonces con gran estrépito de murallas derribadas. Pero, a partir de ese momento, sus consecuencias se desarrollan de manera interrumpida, y no es exagerado pensar que han modelado la historia de nuestro tiempo ${ }^{60}$.

La rebelión, después de todo, no se imagina sino contra alguien. La noción del dios personal, creador, y por lo tanto responsable de todas las cosas, da solo su sentido a la protesta humana. Se puede decir así, y sin paradoja, que la historia de la rebelión es, en el mundo occidental, inseparable de la del cristianismo ${ }^{61}$.

La historia de la rebelión, tal como la vivimos en el presente, es más la rebelión de los hijos de Caín que la de los discípulos de Prometeo. En este sentido es el Dios del Antiguo Testamento, sobre todo, quien movilizará la energía rebelada ${ }^{62}$. 17.

58 A. Camus, El hombre rebelde. Traducción de L. EchávarRI, Buenos Aires ${ }^{9} 1978$,
59 Ib., 27.
$60 \mathrm{lb}$.
61 Ib., 30 .
62 Ib., 35. 


\section{Conclusión}

1. Gn 4 es un texto sobre Caín; la figura de Abel es secundaria. El texto deja en claro que la acción de Caín es reactiva a una iniciativa previa por parte de Yahvé. La búsqueda de una causa para la acción de Yahvé es ajena al texto, que asume la desigualdad, es decir, "la tragedia de la diferenciación", como un hecho de la vida humana. El punto en discusión no es por qué actúa Dios así, sino qué hará Caín frente a ese hecho insoslayable de la existencia. La ubicación del texto en el marco de Gn 1-11 explica la naturaleza fundacional del relato. Es fundacional no porque nos narre un acontecimiento sucedido a un hombre "en los inicios de la historia humana", sino porque lo relatado es, precisamente, un conflicto actual, inherente a la existencia de todo ser humano en las distintas condiciones de su existencia. Es un relato sobre nosotros, hoy.

2. Con la obra de Byron, el motivo de Caín pierde "estrechez dogmática" ${ }^{63}$ y aparece como un problema humano de una profundidad y complejidad inusitadas. Esa corriente de la tradición que ha hecho de Caín nada más que "el tipo de hombre en cuya alma pone su asiento la perversidad" ${ }^{64}$ debe ser superada. Es claro que, como lo ha expresado Unamuno, "si Caín no hubiese matado a su hermano Abel, habría acaso muerto a manos de este" ${ }^{65}$. En un ensayo publicado en 1905 titulado Soledad, Unamuno hace la siguiente reflexión sobre nuestro texto:

Hay quien quisiera haber podido asistir a las conversaciones entre Caín y Abel y haber presenciado la escena que precedió a la muerte de este por aquel. Yo no; habría apartado la vista de ello con horror y asco. Me habría parecido tan falsa y mentirosa la envidia de Caín como mentirosa y falsa la inocencia de su hermano. Yo habría deseado oír a Caín a solas, cuando no tenía a Abel delante, u oírle después, cuando al ser maldito por Dios le dijo, es decir, se dijo a sí mismo: “Grande es mi iniquidad para ser perdonada: he aquí que me echas hoy del haz de la tierra y de tu presencia me esconderé, y andaré errante y extranjero en la tierra, y sucederá que cualquiera que me hallare me matará" (Gn 4,13-14). Y aun para oírle esto era preciso que él no me viera ni supiera que yo le oía, porque entonces me mentiría. Solo me gustaría sorprender los ayes solitarios de los corazones de los demás... ${ }^{66}$

63 E. FRENZEL, Diccionario de argumentos de la literatura universal, Madrid 1976, 74.

${ }^{64}$ E. J. VARona, "El personaje bíblico Caín en las literaturas modernas", en ID., Desde mi Belvedere y otros textos, Caracas 2010, 7.

65 C. Clavería, Temas de Unamuno, Madrid 1953, 98.

66 Ib., 99-100. 
3. La "tragedia de la diferenciación" y la arbitrariedad de la preferencia traen a discusión un tema fundamental en un mundo donde la realidad de las desigualdades sociales hiere permanentemente la conciencia personal. Regina Schwartz pregunta:

¿Por qué Dios condena el sacrificio de Caín? ¿Qué habría pasado si Dios hubiera aceptado ambos sacrificios, promoviendo así la cooperación entre ellos, en lugar de fomentar la competencia y la violencia? ¿Qué clase de Dios es este que escoge arbitrariamente el sacrificio de uno y rechaza el del otro? El Dios que rechaza a uno y prefiere al otro es el Dios monoteísta. Monoteísta porque muestra su favor a uno solamente. Caín mata enceguecido por el dolor que le causa su exclusión... y al matar se convierte en un fuera de ley, en un excluido. Nosotros somos los descendientes de Caín. Nosotros vivimos también en un mundo de excluidos, de competición fatal y feroz en donde unos siempre pierden.

La historia se repite luego con otros dos hermanos, y esa odiosa regla de la escasez aparece nuevamente. ¿No hay suficiente favor divino, suficiente bendición para Jacob y Esaú? ¿Puede prosperar uno solo a expensas del otro? Cuando Jacob roba la bendición a su hermano, no queda ya nada para él: “Esaú insistió: ¿ ¿No tienes más que una bendición, padre mío?¡Bendíceme a mí también, padre mío!'” (Gn 27,38) [...] Y de nuevo el excluido se convierte en fratricida: "A partir de ese momento Esaú guardó un enorme resentimiento contra su hermano y pensaba [...] 'Mataré a mi hermano'” IGn $27,41)^{67}$ (traducción propia).

4. Esta rebeldía de Caín frente a una autoridad arbitraria explica su reivindicación posterior. En Europa, que vivía la época de la monarquía absoluta, la aceptación de la voluntad divina y la aceptación de la voluntad real eran vistas como caras de una misma moneda. El ciudadano debía aceptar las decisiones políticas como parte de la voluntad divina. Con el triunfo de la Revolución francesa emerge un sentido de rebelión social que reivindica la figura de Caín. Este no será ya la encarnación del pecador, sino, por el contrario, la figura del héroe que se rebela contra una tiranía injusta. Este giro en la comprensión del personaje ilustra bien hasta qué punto la realidad social influye en la conformación de las ideas religiosas. Al cambiar el entorno político cambian, correspondientemente, las posibilidades de lectura de un texto, sus personajes y sus temas. La Revolución francesa crea una nueva atmósfera intelectual. Caín se convierte entonces en el símbolo de la rebelión.

5. Las condiciones culturales y espirituales que se empezarán a gestar en Europa a raíz de la Ilustración y el romanticismo permiten que algunos de estos movimientos vean en la acción de Caín un referente. No que

${ }^{67}$ R. M. Schwartz, The Curse of Cain, Chicago-London 1997, 2-4. 
la figura de Caín dé origen a estos movimientos, claro está, sino que la cultura europea de este período ve en la acción de Caín un gesto liberador con el cual se identifica, y su figura se torna, como lo hizo la de Prometeo, en emblemática para una cultura marcada por los motivos y personajes de la herencia judeo-cristiana: "Emancipado, pues, de la divina tutela, que le tendría supuestamente infantilizado, el hombre asumiría sus funciones adultas, que habrían de agigantarse con el tiempo hasta tocar el cielo con sus propias manos, lo mismo que el titán Prometeo" ${ }^{68}$.

José E. RAMírez KidD Universidad Bíblica Latinoamericana

68 C. Díaz, "Prometeísmo", en M. Moreno Villa (ed.), Diccionario del pensamiento contemporáneo, Madrid 1997, 991. 